\title{
MICROSATELLITE POLYMORPHISM IN THREE EGYPTIAN SHEEP BREEDS
}

\author{
M.A. Elfawal ${ }^{1}$, Salah Galal ${ }^{2}$, A. Z. E. Abdelsalam ${ }^{3}$, Mona A. Osman ${ }^{4}$ and \\ M.S. Hassanane ${ }^{1}$ \\ 1- Department of Cell Biology, National Research Center, Giza ,Egypt, 2- \\ Department of Animal Production, Faculty of Agriculture, Ain Shams University, \\ Cairo, Egypt, 3- Department of Genetics, Faculty of Agriculture, Ain Shams \\ University, Shubra Alkhaima, Cairo, Egypt, 4- Department of Sheep and Goat, \\ Animal Production Research Institute, Dokki, Giza, Egypt
}

\section{SUMMARY}

Four microsatellite markers were used to investigate genetic variations among and within three Egyptian sheep breeds; Rahmani, Ossimi, and Saidi. The four microsatellites were OARAE101, BM1329, INRA63 and OARFCB20. All markers tested were found to be polymorphic. The total observed numbers of alleles in the three breeds were 5, 7, 12 and 12 for the four markers respectively, while polymorphism information content (PIC) was 0.660, 0.755, 0.574, and 0.847, respectively. The three breeds showed significant deviation from Hardy-Weinberg equilibrium. The genetic distance test showed that the three breeds had the same cluster of origin but Rahmani showed separate sub-cluster while Ossimi and Saidi are separated together from the other sub-cluster. The average gene diversity was 0.75 for all studied breeds.

Keywords: sheep, microsatellites, Egyptian breeds, Rahmani, Ossimi, Saidi, diversity

\section{INTRODUCTION}

Recent developments in molecular biology enable scientists to develop many useful types of DNA genetic markers to identify genetic variation among and within livestock breeds at the DNA level. Microsatellites are among such markers. They consist of tandem repeats of short sequence motifs, from 2-6bp up to 150bp in length, and were first discovered by Hamada and Kakunaga (1982). A large number of highly polymorphic microsatellites has been characterized and used in mapping quantitative trait loci (Ashwell et al., 2004) and studying the genetic diversity and phylogeny between and within animal breeds (Diez-Tascon et al. 2000; Arranz et al. 2001; Jia et al. 2003; Tapio et al. 2003)

In Egypt, sheep contribute $6 \%$ of the total red meat production (Galal et al., 2005) in addition to their production of wool and manure. Egyptian sheep breeds are fat tailed, their body covered with carpet wool, and are medium in size. Rahmani and Ossimi are among the major breeds in Egypt while Saidi is one of the minor breeds (Galal et al., 2005).

Issued by The Egyptian Society of Animal Production 
Reviewed literature showed only a single study by Hassan et al. (2003) that dealt with the genetic diversity of some microsatellite markers in Ossimi, Rahmani and Barki sheep breeds. The present study (2006) was conducted to investigate the genetic diversity for some sheep breeds using microsatellite markers.

\section{MATERIALS AND METHODS}

\section{Animals}

Hundred adult sheep of both sexes were sampled from two experimental stations, (El-Serw and Seds) belonging to the Animal Production Research Institute (APRI), Egyptian Ministry of Agriculture and Land Reclamation. The system of three matings (Juauary, September and May) per two years was followed where lambs were dropped in June, February and October. Ewes were assigned to the mating groups randomly with the avoidance of sib, ram-daughter and ewe-son matings (Shaat et al., 2004). The numbers within each breed were 35 Ossimi, 32 Rahmani and 33 Saidi. Animals were unrelated up to the third generation.

\section{Blood sampling and DNA isolation}

Ten milliliters of peripheral blood were collected from the animal jugular vein using vacutainer tubes having EDTA as anticoagulant. DNA was extracted using salting out procedure described by Miller et al. (1988).

\section{Microsatellite information}

The microsatellite markers investigated in this study were selected according to MoDAD (FAO, 2004) for the genetic diversity studies. Details of these markers are presented in Table 1.

Table 1. Forward and reverse primer sequences for the studied microsatelites

\begin{tabular}{|c|c|c|}
\hline $\begin{array}{l}\text { Marker } \\
\text { name }\end{array}$ & Primer sequence & Reference \\
\hline BM1329 & $\begin{array}{l}\text { TTGTTTAGGCAAGTCCAAAGTC } \\
\text { AACACCGCAGCTTCATCC }\end{array}$ & $\begin{array}{l}\text { Bishop et al. } \\
\text { (1994) }\end{array}$ \\
\hline OARAE101 & $\begin{array}{l}\text { TAAGAAATATATTTGAAAAAACTGTATCTCCC } \\
\text { TTCTTATAGATGCACTCAAGCTAGG }\end{array}$ & $\begin{array}{l}\text { Montgomery } \\
\text { et al. (1993) }\end{array}$ \\
\hline INRA063 & $\begin{array}{l}\text { ATTTGCACAAGCTAAATCTAACCAAACC } \\
\text { ACAGAAATGCTTGGAAG }\end{array}$ & $\begin{array}{l}\text { Vaiman et al. } \\
\text { (1994) }\end{array}$ \\
\hline OARFCB20 & $\begin{array}{l}\text { AAATGTGTTTAAGATTCCATACAGTG } \\
\text { GGAAAACCCCCATATATACCTATAC }\end{array}$ & $\begin{array}{l}\text { Buchanan et } \\
\text { al. (1994) }\end{array}$ \\
\hline
\end{tabular}

\section{PCR mastermix and run information}

The PCR reaction volume was $20 \mu \mathrm{l}$ for each sample. The PCR mastermix formula contained 50ng/ $\mu \mathrm{l}$ from the DNA template, 10X PCR buffer that included $1.5 \mathrm{mM} \mathrm{MgCl} 2$ and $10 \mathrm{pmol}$ from each forward and reverse primers and $200 \mu \mathrm{M}$ final concentration from each dNTP.The initial PCR cycle was $95{ }^{\circ} \mathrm{C}$ for 3 min then 35 cycles at $95{ }^{\circ} \mathrm{C}$ for $15 \mathrm{sec}$., $55-60{ }^{\circ} \mathrm{C}$ for $30-60 \mathrm{sec}$., $72^{\circ} \mathrm{C}$ for $30 \mathrm{sec}$. and final extension: $72{ }^{\circ} \mathrm{C}$ for $5 \mathrm{~min}$., storage at $15{ }^{\circ} \mathrm{C}$. The PCR products were tested for success on $2 \%$ agarose in TAE buffer in a horizontal electrophoresis chamber and stained with ethidium bromide. The successful runs were subjected to the vertical 
electrophoresis run on $12 \%$ polyacrylamide. The polyacrylamide gels were stained with ethidium bromide and the images were captured using gel documentation system. Allelic sizes were determined using free software Lab. Image V2.7 dispersed free from Proland company (Germany) at http://www.labimaging.com/servlet/ engine/home/start.html. Preparations and staining of the polyacrylamide gels were done using the protocol described by Sambrook et al. 1998.

\section{Statistical analysis}

POPGENE Version 1.31 package was used for estimating allele frequencies, observed and expected numbers of alleles, observed and expected heterozygosity (Nei, 1978), average gene diversity, genetic identity, genetic distance (Nei, 1978), deviation from Hardy-Weinberg using chi square test, and phylogenic analysis using Nei's distance (Nei, 1987). Average gene diversity was calculated according to Nei (1987) for each breed and for all breeds together. The Polymorphism Information Content (PIC), i.e. the probability that one parent is a marker informative and its progeny has different genotype (Lynch and Walsh, 1998), was estimated according to Botstein et al. (1980) as

$$
P I C=1-\sum_{i=1}^{n} P_{i}^{2}-\sum_{i=1}^{n} \sum_{j=i+1}^{n-1} P_{i}^{2} P_{j}^{2},
$$

F-statistics, FIS (the inbreeding coefficient of an individual related to the subpopulation), FIT (the inbreeding coefficient of an individual related to the whole population) and FST (genetic differentiation estimates or the average inbreeding of the subpopulation related to the whole population) were calculated using the updated version from FSTAT software, version 2.9.3.2 (Goudet, 1995). The Tree View 32 software (Page, 1996) was employed to draw the dendrogram showing the genetic distances and relationships between the breeds understudy.

\section{RESULTS AND DISCUSSION}

\section{Observed number of alleles}

All microsattelites used in the present study showed polymorphism in all the studied breeds. Table 2 presents the number of observed alleles for each of the four microsattelite loci. The total number of detected alleles was 5 for BM1329, 7 for OARAE101 and 12 for each of INRA063 and OARFCB20. Histograms 1 to 4 show the allele frequencies in the populations under study. In the present study the bovine microsattelite BM1329 showed 5 alleles ranging in size from 168 to186 bp, while this microsatellite showed 6 alleles in the Chinese sheep breeds (Chu et al., 2001) and 9 alleles in Blanca Andaluza goat (Martinz et al., 2004). Although this marker is from bovine origin, it cross-hybridized with sheep and goat DNA. FAO (2004) recommended it for the use in sheep and goat genetic diversity studies. The microsatellite OARAE101 showed 7 alleles ranging in size from 105 to $123 \mathrm{bp}$, while it showed 9 alleles in the Chinese sheep breeds (Chu et al., 2001), and 4 alleles in Small Tail Han sheep (Chu et al., 2002). The microsatellite INRA063 showed 12 alleles with a size range $163 \sim 211 \mathrm{bp}$, while this microsatellite showed 19 alleles in the Swiss sheep breeds by Saitbekova et al. (2000) and 7 alleles in Swiss goat breeds (Saitbekova et al., 1999). Finally, the microsattelite OARFCB20 showed 12 alleles 
ranging in size from 92 to $125 \mathrm{bp}$. This microsatellite showed 10 alleles in Rasa Aragonesa sheep of Spain (Arruga et al., 2001).

Table 2. Observed number of alleles for different microsatelites and different breeds

\begin{tabular}{|c|c|c|c|c|c|c|}
\hline \multirow{2}{*}{ Breed } & \multicolumn{4}{|c|}{ Microsatellite allele } & \multirow{2}{*}{ Total } & \multirow{2}{*}{$\begin{array}{l}\text { Mean } \\
\text { per } \\
\text { breed }\end{array}$} \\
\hline & BM1329 & OARAE101 & INRA063 & OARFCB20 & & \\
\hline Rahmani & 5 & 3 & 10 & 8 & 26 & 6.5 \\
\hline Ossimi & 5 & 6 & 11 & 9 & 31 & 7.75 \\
\hline Saidi & 5 & 7 & 10 & 12 & 34 & 8.5 \\
\hline
\end{tabular}

The data in Table 2 show that Saidi breed had the highest average number of alleles while Rahmani showed the lowest. Saidi sheep are named after Upper Egypt (Said) which extends from the south of Cairo to the border with Sudan. The breed having more alleles than the other two breeds could indicate that it is a mixture of populations. Phenotypically, both Rahmani and Ossimi sheep have uniform and distinct phenotypes from each other while Saidi have a mixture of colors, tail shapes and horns etc.

\section{Allele frequencies}

Details of the observed number of microsatellite alleles, their sizes and frequencies are presented in Tables from 3 to 6 and the Histograms from 1 to 4 .

Table 3. Allele size and frequency for microsatellite BM1329

\begin{tabular}{crrrrr} 
Allele number & \multicolumn{2}{l}{$\begin{array}{l}\text { Allele } \\
\text { size (bp) }\end{array}$} & \multicolumn{2}{l}{ Allele frequency } & \multicolumn{2}{l}{ Rahmani } & Ossimi & Saidi & All breeds \\
\cline { 3 - 6 } & 166 & 0.437 & 0.343 & 0.410 & 0.396 \\
2 & 174 & 0.203 & 0.057 & 0.060 & 0.104 \\
3 & 176 & 0.016 & 0.143 & 0.091 & 0.084 \\
4 & 182 & 0.016 & 0.414 & 0.167 & 0.203 \\
5 & 186 & 0.328 & 0.043 & 0.273 & 0.213 \\
\hline
\end{tabular}

Table 4. Allele size and frequency for microsatellite OARAE101

\begin{tabular}{cccccc}
\hline Allele number & $\begin{array}{l}\text { Allele } \\
\text { size (bp) }\end{array}$ & \multicolumn{4}{c}{ Allele frequency } \\
\cline { 3 - 6 } & & Rahmani & Ossimi & Saidi & All breeds \\
\hline 1 & 105 & 0 & 0.028 & 0.030 & 0.020 \\
2 & 108 & 0 & 0 & 0.136 & 0.046 \\
3 & 111 & 0 & 0.023 & 0.182 & 0.071 \\
4 & 114 & 0 & 0.040 & 0.091 & 0.047 \\
5 & 117 & 0.445 & 0.310 & 0.140 & 0.306 \\
6 & 120 & 0.055 & 0.030 & 0.060 & 0.036 \\
7 & 123 & 0.500 & 0.580 & 0.361 & 0.474 \\
\hline
\end{tabular}


Table 5. Allele size and frequency for microsatellite INRA63

\begin{tabular}{cccccc}
\hline Allele no & \multicolumn{1}{l}{$\begin{array}{l}\text { Allele } \\
\text { size (bp) }\end{array}$} & \multicolumn{4}{c}{ Allele frequency } \\
\cline { 2 - 6 } & 163 & 0.094 & 0.143 & 0.136 & 0.119 \\
1 & 165 & 0.016 & 0.086 & 0 & 0.038 \\
2 & 169 & 0.016 & 0.043 & 0.015 & 0.025 \\
3 & 175 & 0.313 & 0.257 & 0.106 & 0.228 \\
4 & 179 & 0.063 & 0.029 & 0.015 & 0.030 \\
5 & 185 & 0.078 & 0.157 & 0.060 & 0.109 \\
6 & 189 & 0.125 & 0.014 & 0 & 0.055 \\
7 & 195 & 0.172 & 0.1 & 0.242 & 0.163 \\
8 & 197 & 0 & 0 & 0.030 & 0.010 \\
9 & 199 & 0.094 & 0.086 & 0.136 & 0.104 \\
10 & 201 & 0.031 & 0.029 & 0.030 & 0.030 \\
11 & 211 & 0 & 0.057 & 0.227 & 0.094 \\
12 & & 0 & & & Saidi \\
\hline
\end{tabular}

Table 6. Allele size and frequency for microsatellite OARFCB20

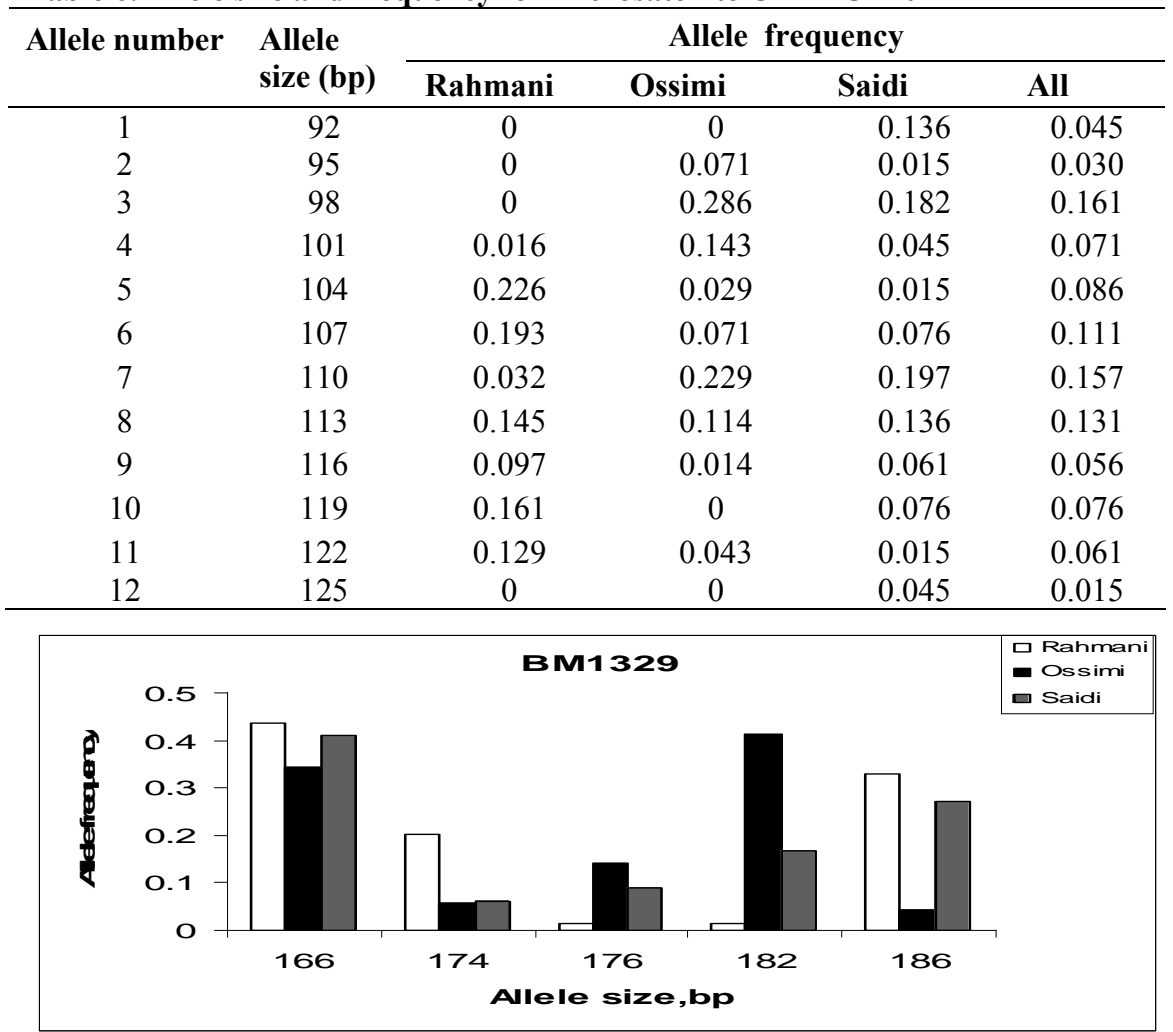

Histogram 1. Allele frequency for microsatellite BM1329 in Rahmani,Ossimi and Saidi breeds 


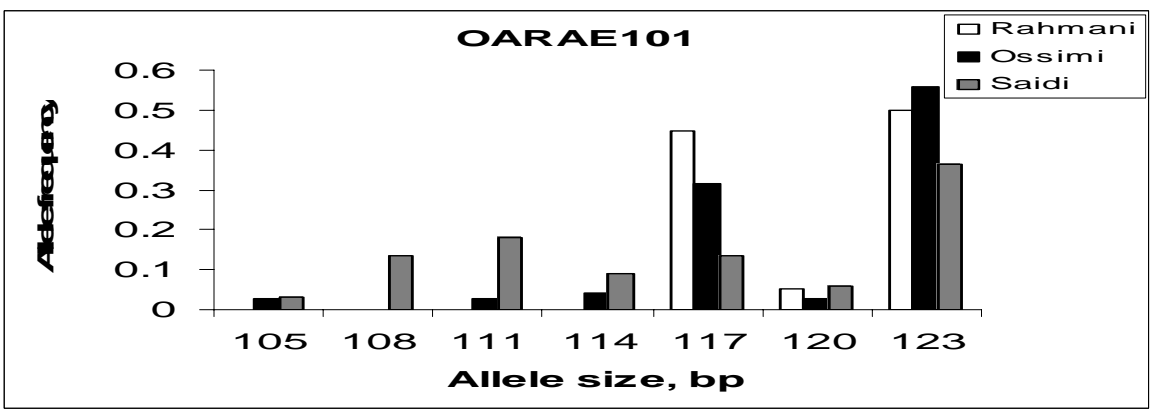

Histogram 2. Allele frequency for microsatellite OARAE101 in Rahmani, Ossimi and Saidi breeds

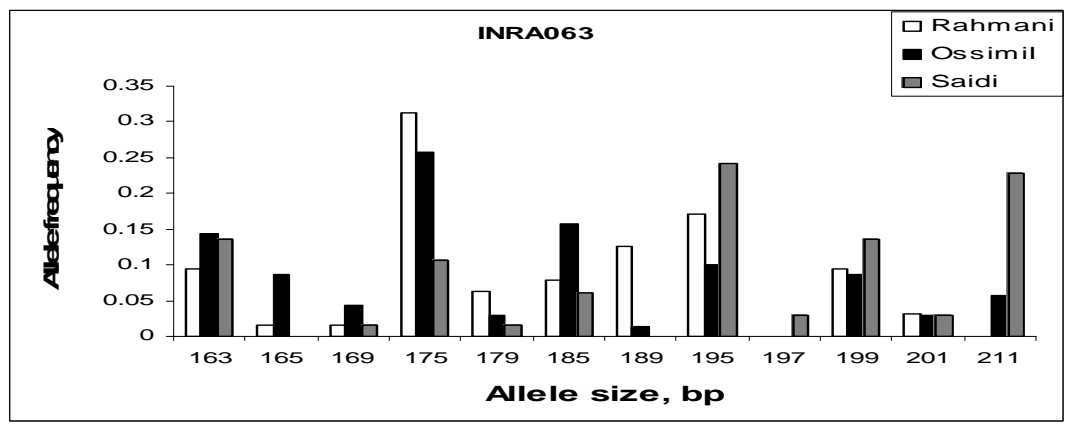

Histogram 3. Allele frequency for microsatellite INRA063 in Rahmani, Ossimi and Saidi breeds

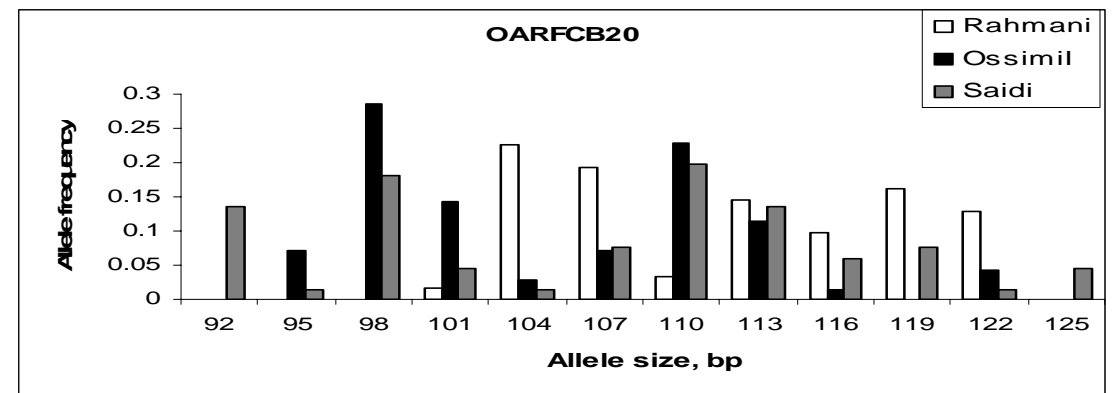

Histogram 4. Allele frequency for microsatellite OARFCB20 in Rahmani, Ossimi and Saidi breeds

\section{Exclusive and prevailing alleles}

Exclusive alleles refer to unique alleles or breed specific alleles while prevailing alleles refer to common alleles with the highest frequency among the populations. The exclusive alleles always have extreme value small or large frequency (Arranz et al. 2001). Exclusive alleles were reported in different sheep breeds. Hassan et al. (2003) reported that 6 alleles out of 40 were exclusive in some Egyptian sheep 
breeds. Buchanan et al. (1994) reported exclusive alleles in Bighorn sheep, Forbes et al. (1995) found unique alleles in domestic and Bighorn sheep and Arranz et al. (2001) found breed specific alleles in Spanish Merino. Farid et al. (1999) found 17 out of 93 alleles in one breed with low frequency in some Canadian sheep breeds. Grigaliunaite et al. (2003) reported that from 175 alleles, there were 36 unique alleles with no correlation reported between the mean number of alleles and the exclusive alleles in Baltic sheep breeds. Li et al.(2002) reported unique alleles with high frequency 0.74 in some Chinese sheep breeds, while Yang et al.(1999) reported that 3 alleles of 57 were found as breed specific.

In the present study, Saidi breed showed exclusive alleles in markers OARAE101, INRA063, and OARFCB20 with allele frequency $(0.1364),(0.030)$, and (0.045-0.1364), respectively (Tables 4,5,6). This result may be due to the wide distribution of Saidi breed which might have imported the unique alleles from unknown breeds during a gene flow process. The prevailing and exclusive alleles are shown in Histograms 1 to 4.

\section{Observed and expected heterozygosity}

Heterozygosity is a recognized parameter that reflects genetic variability within breed (Arranz et al. 2000). Observed and expected heterozygosity for the different markers in the studied breeds are presented in Table (7). The high genetic heterozygosity could be a normal results of mixed generations, mixed populations from different territories, genetic drift, and natural selection (Grisez-Duranton et al., 2002). The Ossimi and Rahmani breeds showed similar result of an average expected heterozygosity 7.22 and 7.49 respectively (Table 7 ). The average gene diversity of the Rahmani, Ossimi, Saidi was 0.751. Saidi breed showed the highest value of expected heterozygosity $(0.815)$, which could be explained by the possibilty of the breed being a mix of many populations in Upper Egypt.

Table 7. Microsatellite alleles (No, observed number of alleles Ne, effective number of alleles), heterozygosity (Hto, observed; Hte, expected) and Polymorphism Information Content (PIC) at each locus in the different breeds

\begin{tabular}{|c|c|c|c|c|c|c|c|}
\hline \multirow{2}{*}{ Breed } & & & \multicolumn{5}{|c|}{ Locus } \\
\hline & & & \multicolumn{3}{|c|}{ BM1329 OARAE101 INRA063 } & \multicolumn{2}{|c|}{ OARFCB20 Mean } \\
\hline \multirow{5}{*}{ Rahmani } & \multirow{2}{*}{ Allele } & No & 5 & 3 & 10 & 8 & 6.5 \\
\hline & & $\mathrm{Ne}$ & 2.93 & 2.2 & 5.82 & 6.14 & 4.25 \\
\hline & \multirow[b]{2}{*}{ Het } & Hto & 0.8 & 1.000 & 0.9 & 1.000 & 0.914 \\
\hline & & Hte & 0.67 & 0.556 & 0.841 & 0.851 & 0.722 \\
\hline & PIC & & 0.626 & 0.495 & 0.291 & 0.827 & ------ \\
\hline \multirow{5}{*}{ Ossimi } & \multirow{2}{*}{ Allele } & No & 5 & 6 & 11 & 9 & 7.8 \\
\hline & & $\mathrm{Ne}$ & 3.177 & 2.41 & 6.93 & 5.623 & 4.552 \\
\hline & \multirow{2}{*}{ Het } & Hto & 0.943 & 0.778 & 0.833 & 0.944 & 0.875 \\
\hline & & Hte & 0.695 & 0.594 & 0.868 & 0.834 & 0.75 \\
\hline & PIC & & 0.658 & 0.991 & 0.607 & 0.811 & --------- \\
\hline \multirow{5}{*}{ Saidi } & \multirow[t]{2}{*}{ Allele } & No & 5 & 7 & 10 & 12 & 8.500 \\
\hline & & $\mathrm{Ne}$ & 3.553 & 4.644 & 6.084 & 7.751 & 5.508 \\
\hline & \multirow[t]{2}{*}{ Het } & Hto & 0.909 & 0.939 & 0.849 & 0.758 & 0.864 \\
\hline & & Hte & 0.730 & 0.797 & 0.849 & 0.884 & 0.815 \\
\hline & PIC & & 0.696 & 0.781 & 0.826 & 0.906 & ------- \\
\hline
\end{tabular}




\section{Hardy-Weinberg equilibrium( $\mathrm{HWE}$ )}

All studied breeds showed a highly significant deviation from HWE in all studied loci. This result could be due to a disequlibrium created by selection practiced in the stations and that the flocks were sampled immediately after the scarificial season of Eid al-Adha when many animals were sold out from the flocks.

\section{Polymorphism information content (PIC)}

PIC indicates the genetic variation, markers with high PIC value are considered highly informative markers (Arora et al., 2004). All studied markers were highly informative, PIC was 0.626, 0.658, and 0.696 for BM1329 marker, 0.495, 0.99, and 0.781 for OARAE101 marker, $0.29,0.6$ and 0.826 for INRA063 marker and 0.826, 0.81 and 0.90 for OARFCB20 marker in Rahmani, Ossimi and Saidi breeds, respectively (Table 7).

\section{Inbreeding measures}

Inbreeding coefficient is defined as the correlation between uniting gametes also called coefficient of consanguinity (Lush, 1948). The inbreeding within populations $\left(\mathrm{F}_{\mathrm{IS}}\right)$ is presented in Table 8 . The average of $\mathrm{F}_{\mathrm{IS}}$ in all studied loci showed that the individuals were generally outbred. Rahmani sheep were outbred in all the studied loci, Ossimi showed inbreeding in one locus (INRA063) with very small value (0.026) while Saidi showed inbreeding in two loci (INRA063 and OARFCB20). Hassan et al. (2003) reported higher estimates of inbreeding in Ossimi and Rahmani from private farms ( 0.315 and 0.289 , respectively) as compared to -0.204 and -0.316 , respectively in the present study. This result could be due to the practice by the experimental station to buy rams from other flocks to avoid inbreeding

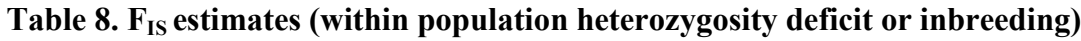
for each of the studied loci

\begin{tabular}{lccc}
\hline Locus & & Breed & \\
\hline & Rahmani & Ossimi & Saidi \\
BM1329 & -0.185 & -0.365 & -0.265 \\
OARAE101 & -0.830 & -0.329 & -0.197 \\
INRA063 & -0.056 & 0.026 & 0.020 \\
OARFCB20 & -0.194 & -0.149 & 0.130 \\
Average & -0.316 & -0.204 & -0.311 \\
\hline
\end{tabular}

The total inbreeding coefficient of an individual related to whole population $\left(\mathrm{F}_{\mathrm{IT}}\right)$ is shown in Table 9. All breeds under study showed high amount of heterozygosity (negative $\mathrm{F}_{\mathrm{IT}}$ ). All studied loci showed high heterozygosity excess, $\mathrm{F}_{\mathrm{IT}}$ ranging from -0.339 (OARAE101) to -0.008 (OARFCB20). The means of all the studied loci showed an excess of heterozygosity and outbreeding for all studied markers. In contrast to this study, Hassan et al. (2003) reported a total inbreeding of 0.255.

$\mathrm{F}_{\mathrm{ST}}$ is the average inbreeding of the breed related to the whole population (Falconer and Mackay, 1996) and it is a measure of differentiation among populations. $\mathrm{F}_{\mathrm{ST}}$ estimates indicate that the most informative marker as far as genetic differentiation is concerned was BM1329 (0.0693) and the least was INRA063 $(0.0326)$ for the studied breeds (Table 9) 
Table 9. F statistics for the studied populations

\begin{tabular}{lcc}
\hline Locus & $\mathbf{F}_{\text {IT }}$ & $\mathbf{F}_{\text {ST }}$ \\
\hline BM1329 & -0.188 & 0.069 \\
OARAE101 & -0.340 & 0.052 \\
INRA063 & -0.321 & 0.032 \\
OARFCB20 & -0.008 & 0.056 \\
Mean & -0.108 & 0.052 \\
\hline
\end{tabular}

The pair-wise comparisons of breed differentiation shown in Table 10 (upper diagonal) indicate low genetic differentiation between the investigated breeds. Hassan et al. (2003) reported that $\mathrm{F}_{\mathrm{ST}}$ was 0.024 between Ossimi and Rahmani from the private farms as compared to 0.048 in the present study.

Table 10. Estimated pair-wise $F_{S T}$ as a measure of the genetic differentiation between breeds (upper diagonal) and gene flow (lower diagonal) between pairs of the studied sheep breeds

\begin{tabular}{lccc}
\hline Breed & Rahmani & Ossimi & Saidi \\
\hline Rahmani & -------- & 0.048 & 0.040 \\
Ossimi & 4.954 & ------ & 0.030 \\
Saidi & 5.912 & 8.028 & ------ \\
\hline
\end{tabular}

Gene flow

Gene flow was estimated according to Nei (1987) as Nm indicating the ratio of the migrants exchanged from one generation to another. The lowest value of genetic differentiation between the breeds is confirmed by the high level of gene flow between each two breeds (Table 10). The highest value of the gene flow was observed between Ossimi and Saidi breeds which also have the lowest value of $\mathrm{F}_{\mathrm{ST}}$, as a genetic differentiation. This could be explained by the geographical proximity of the two breeds.

\section{Genetic distance and identity}

Genetic distance and genetic identity showed small differences and high genetic similarity between each two breeds (Table 11) Ossimi and Saidi showed the smallest genetic distance $(0.218)$ and the highest genetic similarity $(0.804)$. This agrees with the close geographical origin of the two breeds (Figure 1).

Table 11. Nei's genetic identity (upper diagonal) and genetic distance (lower diagonal)

\begin{tabular}{lccc}
\hline Breed & Rahmani & Ossimi & Saidi \\
\hline Rahmani & ----- & 0.738 & 0.737 \\
Ossimi & 0.303 & ---- & 0.804 \\
Saidi & 0.304 & 0.217 & ---- \\
\hline
\end{tabular}




\section{Genetic divergence}

Genetic divergence is another measure of how breeds divert from each other in terms of time. Nei (1978) calculated genetic divergence (Ds) as

$$
\begin{aligned}
\text { Ds } & =2 \alpha \mathrm{t}, \\
\mathrm{t} & =\mathrm{Ds} *(2 \alpha)-1
\end{aligned}
$$

where $\alpha$ is the microsatellite mutation rate and $t$ is the number of generations.

The average mutation rate of 28 human loci $\left(1.2 * 10^{-3}\right)$ as reported by Weber and Wong (1993) and generation interval in these Egyptian sheep breeds of 4.35 years (Shaat et al., 2004) were used in the present study to calculate the number of years separating any two breeds. Genetic divergence analysis shows that the divergence time was 549 years between Rahmani and Ossimi, 394 between Ossimi and Saidi and 552 between Rahmani and Saidi (Table12).

Table 12. Estimated divergence time of the breeds under study on the basis of the 4 microsatellite loci studied.

\begin{tabular}{lccc}
\hline & & \multicolumn{2}{c}{ Divergence time } \\
\cline { 3 - 4 } Breed & Ds & t, generations & Year \\
\hline Rahmani \& Ossimi & 0.3031 & 126.29 & 549 \\
Rahman i\& Saidi & 0.3047 & 126.95 & 552 \\
Ossimi \& Saidi & 0.2176 & 90.66 & 394 \\
\hline
\end{tabular}

\section{Relationship Dendrogram}

Relationship dendrogram showed that Ossimi and Saidi were separated together in one sub cluster while Rahmani was located in the other sub cluster (Figure 1).

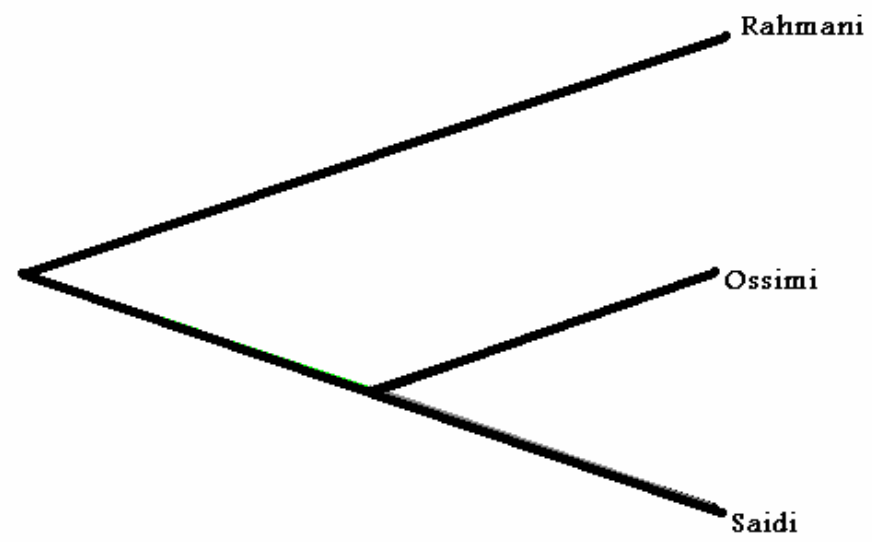

Figure 1. Phylogenetic tree representing relationship among the breeds under study using genetic distance based on four microsatellite loci 


\section{CONCLUSION}

It could be concluded that while the three breeds are generally closely related, the Ossimi and Saidi are related to each other more than to the Rahmani, and that Saidi sheep are the most diverse among the three Egyptian breeds.

\section{REFERENCES}

Arora, R., B.D.Lakhchaura, R.B. Prasad, M.S. Tantia, and R.K. Vijh, 2004. Genetic diversity analysis of two buffalo populations of northern India using microsatellite markers. Journal of Animal Breeding and Genetics. 121 (2):111118.

Arranz, J. J., Y. Bayon, and F. San Primitivo, 2001. Differentiation among Spanish sheep breeds using microsatellites. Genet. Sel. Evol. 33 (5): 529-542.

Arranz, J.J., Y. Bayon, and F. San Primativo, 2000. Genetic variation at microsatellite loci in Spanish sheep. Small Ruminant Research. 39: 3-10.

Arruga, M. V., L. V. Monteagudo, M. T. Tejedor, R. Barrao and R. Ponz, 2001. Analysis of microsatellites and paternity testing in Rasa Aragonesa sheep. Research in Veterinary Science. 70: 271-273.

Ashwell, M.S., D. W. Heyen, T.S. Sonstegard, C.P. Van Tassell, Da, Y. VanRaden, P.M. Ron, M. Weller, J.I. and H.A. Lewin, 2004. Detection of quantitative trait loci affecting milk production, health, and reproductive traits in Holstein cattle. J. Dairy Sci. 87 (2): 468-475.

Bishop, M.D., S.M. Kappes, J.W. Keele, R.T. Stone, S.L.F. Sunden, G.A. Hawkins, S. Solinas Toldo, R. Fries, M.D. Grosz, J. Yoo, and C.W. Beattie, 1994. A genetic linkage map for cattle. Genetics 136: 619-639.

Botstein, D., R.L. White, M. Skolnick, and R.W. Davis, 1980. Construction of genetic linkage maps in man using restriction fragment length polymorphisms. American Journal of Human Genetics. 32: 314-331.

Buchanan, F.C., S.M. Galloway, and A.M. Crawford, 1994. Ovine microsatellites at the OarFCB5, OarFCB19, OarFCB20, OarFCB48, OarFCB129 and OarFCB226 loci. Anim Genet. 25 (1): 60.

Chu, M. X., J. Z. Wang, A. G. Wang, N. Li and J. L. Fu, 2002. Genetic polymorphisms of five microsatellite loci in Small Tail Han sheep. Yi Chuan Xue Bao. 29(6): 502-506. www.pubmed.com. September 2005

Chu, M. X., J. H. Cheng and W. Guo, 2001. Preliminary studies of microsatellite markers OarAE101 and BM1329 in five sheep breeds. Yi Chuan Xue Bao. 28(6):510-517. www.pubmed.com. September 2005

Diez-Tascon, C., R.P. Littlejohn, P.A. Almeida, and A.M. Crawford, 2000. Genetic variation within the Merino sheep breed: analysis of closely related populations using microsatellites. Anim, Genet. 31 (4): 243-251.

Falconer, D.S, and T.F.C. Mackay, 1996. Introduction to Quantitative Genetics. Longman Scientific and Technical, Longman Group UK Ltd. 90-99.

FAO, (2004): Secondary Guidelines for Development of National Farm Animal Genetic Resources Management Plans, Measurement of Domestic Animal diversity (MoDAD), Recommended Microsatellite Markers, Rome, Italy. 
Farid, A., E. Oreilly, C. Dollard and C. R. Kelsey, 1999. Genetic analysis of ten sheep breeds using microsatellite markers. Canadian Journal of Animal Science. 10: 9-17.

Forbes, S.H., J.T. Hogg, F.C. Buchanan, A. M. Crawford, and F.W. Allendorf, 1995. Microsatellite evolution in congeneric mammals: domestic and bighorn sheep. Mol. Biol. Evol. 12:1106-1113.

Galal, S., F. Abdel-Rasoul, M.R. Anous, and I.M. Shaat, 2005. On-station Characterization of Small Ruminant Breeds in Egypt. In Characterization of Small Ruminant Breeds in West Asia and North Africa, Vol. 2, 141-193 Luis Iniguez (Ed.), ICARDA, Aleppo, Syria.

Goudet, J, 1995. FSTAT version 1.2: a computer program to calculate F statistics. Journal of Heredity. 86 (6): 485-486.

Grigaliunaite, I., M. Tapio, H. Viinalass, Z. Grislis, J. Kantanen, and I. Miceikiene, 2003. Microsatellite variation in the Baltic sheep breeds. Veterinarija Ir Zootechnika. 21(43): 66-73.

Grisez-Duranton, C., P. Dorchies, J. Jourdane and P. Durand, 2002. Genetic structure of Oestrus ovis populations in sheep and goats. Veterinary Parasitology. 104: 167-173.

Hamada, H. and T. Kakunaga, 1982. Potential Z-DNA forming sequences are highly dispersed in the human genome. Nature. 298: 396-398.

Hassan, A.A. Abou A.A. Mosallam, H.A. Oraby, de H.A. Hondt and S.M. El Nahas, 2003. Genetic Diversity of Three Sheep Breeds in Egypt Based on microsatellitees Analysis. J. Eng. and Biotechnol. (NRC). 1 (1): 141-150.

Jia, B., J. Chen, R.Q. Zhao, Q. Luo, G.Q. Yan, and J. Chen, 2003. Microsatellite analysis of genetic diversity and phylogenetic relationship of eight sheep breeds in Xinjiang. Yi Chuan Xue Bao. 30 (9): 847-854.

Li, M.H. S.H. Zhao, C. Bian, H.S. Wang, H. Wei, B. Liu, M. Yu, B. Fan, S.L. Chen, M.J. Zhu, S.J. Li, T.A. Xiong, and K. Li, 2002. Genetic relationships among twelve Chinese indigenous goat populations based on microsatellite analysis. Genet. Sel. Evol. 34(6): 729-744.

Lush, J.L., 1948. The Genetics of Populations. Iowa State University, Ames, Iowa, USA, pp 900.

Lynch, M. and B. Walsh. 1998. Genetics and Analysis of Quantitative Traits. Sinauer Association, Inc. Massachusetts, USA, 492-495.

Martínez, A.M., M.P. Carrera, J.M. Acosta, P.P. Rodríguez-Gallardo, A. Cabello, E. Camacho and J.V. Delgado, 2004. Genetic characterization of the Blanca Andaluza goat based on microsatellite Markers. South African Journal of Animal Science. 34: 17-19.

Miller, S.A., D.D. Dykes, and H.F. Polesky, 1988. A simple salting out procedure for extracting DNA from human nucleated cells. Nucleic Acids Research. 16: 1215.

Montgomery, G.W., A.M. Crawford, J.M. Penty, K.G. Dodds, A.J. Ede, H.M. Henry, C.A. Pierson, E.A. Lord, S.M. Galloway and A.E. Schack, 1993. The ovine Booroola fecundity gene $(\mathrm{FecB})$ is linked to markers from a region of human chromosome 4q. Nature Genetics. 4: 410-414.

Nei, M. 1978. Estimation of average heterozygosity and genetic distance from a small number of individuals. Genetics. 89: 583-587. 
Nei, M. 1987. Molecular Evolutionary Genetics, pp512. Columbia University Press, New York, USA.

Page, R.D. 1996. TREEVIEW: an application to display phylogenetic trees on personal computers. Comput. Appl. Biosci. 12: 357-358.

Saitbekova, N. C. Gaillard, G. Obexer-Ruff, and G. Dolf, 1999. Genetic diversity in Swiss goat breeds based on microsatellite analysis. Animal Genetics. 30: 36-41.

Sambrook, J., E.F. Fritsch, and T. Maniatis, 1989, Molecular Cloning-A Laboratory Manual, Cold Spring Harbor Laboratory Press.

Shaat, I., S. Galal, and H. Mansour, 2004. Genetic trends for lamb weights in flocks of Egyptian Rahmani and Ossimi sheep. Small Ruminant Research.51: 23-28.

Tapio, M., I. Miceikiene, J. Vilkki, and J. Kantanen, 2003. Comparison of microsatellite and blood protein diversity in sheep: inconsistencies in fragmented breeds. Mol. Ecol. 12 (8): 2045-2056.

Vaiman, D., D. Mercier, K. Moazami-Goudarzi, 1994. A set of 99 cattle microsatellites: characterisation, synteny, mapping, and polymorphism. Mamm. Genome. 5 (5): 288-297.

Weber, J. L. and C. Wong. 1993. Mutation of human short tandem repeats. Hum. Mol. Genet. 2: 1123-1128.

Yang, L., S.H. Zhao, K. Li, Z.Z. Peng, and G.W. Montgomry, 1999. Determination of genetic relationship among five indigenous Chinese goat breeds with six microsatellite markers. International Society for Animal Genetics. 30: 452-455. 
التعدد الثكلى فى التوابع الدقيقة لثلاثة سلالات أغنام مصرية

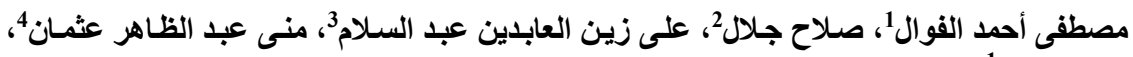
محمد صابر 1 حسانين

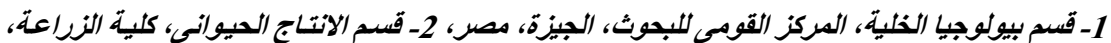

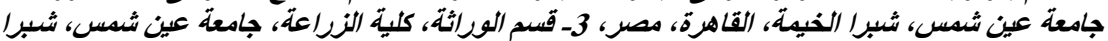

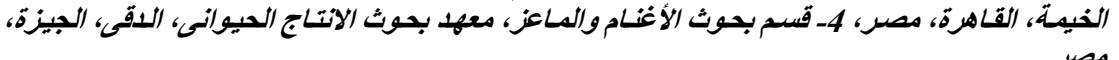

أستخدمت أربعة واسمات للتو ابع الدقيقة لتوضيح الاختلافات الور اثية بين وداخل ثلاثثة سـلالات من الأغنام

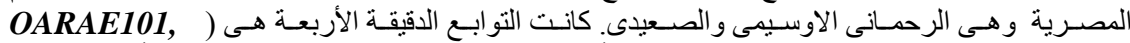
(BM1329, INRA63 and OARFCB20

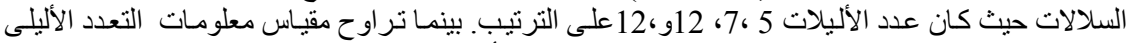

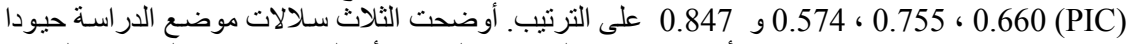

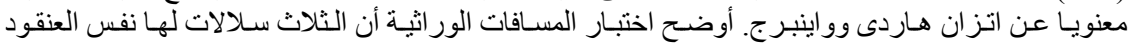

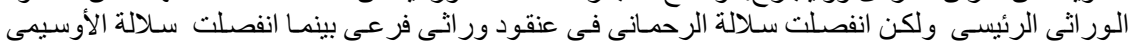
و الصعيدى فى العنقود الور اثى الفرعى الآخر. كان منوسط التنو على الجينى فى كل السلالات فلى المدروسة 0.75 ـ 